\title{
Mitochondrial DNA variation in North American melanopline grasshoppers
}

\author{
W. CHAPCO*, R. A. KELLN** \& D. A. MCFADYEN $\dagger$ \\ Departments of Biology* and Chemistry**, University of Regina, Regina, Saskatchewan, Canada, S4S OA2
}

\begin{abstract}
Restriction fragment analysis of mitochondrial DNA (mtDNA) was used to examine genetic variation within and among 11 species of grasshoppers in the subfamily Melanoplinae. Total DNA of 236 individuals was digested with 10 restriction enzymes and probed with three cloned EcoRI fragments representing the entire mitochondrial genome of Melanoplus sanguinipes. The average size of mtDNA for these species was about 16.1 kilobases. Average nucleotide diversities within species ranged from 0.00 to 0.31 per cent. Values are considered low and possibly reflect chronically small population sizes in pre-agricultural times as well as bottlenecks engendered by various glacial episodes. Species regarded as major pests appear to have larger diversities. For each species, common genotypes occur throughout the sampled region suggesting very little spatial differentiation although in a couple of melanoplines, one or two haplotypes are geographically restricted. Comparisons among species led to a hypothesis concerning their phylogenetic relationships. Not all affinities accorded with expectations based on morphological comparisons. The estimated time of divergence for the genus Melanoplus is at least 4 million years.
\end{abstract}

Keywords: grasshoppers, Melanoplus, mitochondrial DNA, population structure, phylogeny.

\section{Introduction}

Contemporary orthopterists recognize about five subfamilies of North American Acrididae (Otte, 1981; Vickery \& Kevan, 1986). The largest one, Melanoplinae, is dominated by the genus Melanoplus, comprising over 80 species (Helfer, 1987). These include species of economic importance, such as the migratory grasshopper $M$. sanguinipes and, up to the turn of the century, the notorious Rocky Mountain grasshopper M. spretus (Lockwood, 1989), now extinct. In spite of their obvious agricultural impact and dominance as grazing herbivores in prairie communities (Otte, 1981), very little is known about the systematic relationships among the various species in this subfamily. Availability of phylogenetic information would not only satiate the curiosity of acridologists but could, for example, provide an evolutionary perspective for comprehending factors which underlie pest status.

Melanoplines differ in their distribution ranges, habitats, food preferences and bionomics (Brooks, 1958; Vickery \& Kevan, 1986), egg and egg pod characteristics (Onsager \& Mulkern, 1963), nymphal

*Correspondence.

$\nmid$ Present address: Department of Genetics, University of Alberta, Edmonton, Alberta, Canada, T6G 2E1. external features (Handford, 1946), and isozyme patterns (Chapco, 1989). Species are generally identified by genital characteristics of the male. By contrast, females of some species are difficult to distinguish, at least those which, according to Helfer (1987), are deemed closely related. Attempts have been made, based on morphology, to erect several 'species-groups' or 'series' (Scudder, 1898; Gurney, 1977) but no indication is given as to how the species-groups are interconnected among themselves. It would seem that Brooks' (1958, p. 19) statement regarding Melanoplus that 'at present the exact relationship of the many species (of Melanoplus) is unknown' is still true today. Splitting the genus has been proposed on the basis of its heterogeneity (Vickery, 1987) and some unpublished cytological results (Vickery \& Scudder, 1987) but the exact nature of this division should await a more complete genetic analysis, preferably one based on a variety of independent traits.

One trait that has been exploited extensively for addressing both population genetics and systematics issues is based on mitochondrial DNA (mtDNA) investigations (Wilson et al., 1985; Avise et al., 1987). Advantages and properties of the macromolecule rendering it suitable for such research are well known and have been reviewed elsewhere (Harrison, 1989). In this paper, an analysis of fragment patterns generated 
by restriction enzyme digestion of mtDNA obtained from several melanopline species is presented. The objective is twofold. The first is to compare and contrast levels of variation and population structures among species, some of which differ in their status as pests, and the second aim is to establish a phylogeny of these species whereby connections among members can be compared with those suggested by the taxonomic literature.

\section{Materials and methods}

Relevant data for $M$. sanguinipes reported previously (Chapco et al., 1992) have been extracted and are summarized and included here for comparative purposes. Eight other species of the genus Melanoplus were assayed for their mtDNA fragment patterns: $M$. angustipennis, $M$. bivittatus, $M$. confusus, $M$. dawsoni, $M$. femurrubrum, $M$. gladstoni, $M$. infantilis and $M$. packardii. Two other melanoplines, Hesperotettix viridis and Phoetaliotes nebrascensis were included and their status as potential outgroup species was explored. A total of 236 individuals was collected during 1989 and 1990 from 19 locations in Saskatchewan and the following places outside the province: Mauston, Wisconsin; Alexandria, Minnesota; Turtle Lake, North Dakota; Santa Fe, New Mexico and Tobermory, Ontario (Appendix A).

Methods of mtDNA isolation, restriction endonuclease digestion of total DNA, gel electrophoresis, Southern transfer, radiolabelling of probes and hybridization are described in Chapco et al. (1992). Three EcoRI fragments of 8.0, 6.8 and $1.2 \mathrm{~kb}$ cloned into pUC18 and representing the entire mitochondrial genome of $M$. sanguinipes were used collectively to probe mtDNA of each species.

Restriction enzyme profiles were designated as a sequence (haplotype) of 10 uppercase letters AAAAAAAAAA, BAAAAAAAAA, etc. where each letter refers to a particular 'morph' or fragment pattern produced by each of the restriction enzymes: EcoRI, BglII, PstI , AccI, PvuII, XbaI, HinfI, HpaI, AluI and DraI, respectively. Nucleotide diversities $(\delta)$ between pairs of haplotypes were estimated according to equations 5.52 to 5.55 in Nei (1987). In addition, average nucleotide diversities $\langle\pi\rangle$ within species and between species (corrected for within-species variation) were calculated; these indices take into account haplotype frequencies (Nei \& Li, 1979). To discern patterns of relationship among taxa, the matrix of interspecific $\pi$ values was analysed by Saitou and Nei's (1987) neighbour-joining (NJ) method. Haplotypes were also converted into strings of $1 \mathrm{~s}$ and $0 \mathrm{~s}$ for cladistic analysis using the PHYLIP programs, MIX and CONSENSE, provided by J. Felsenstein (1988).

Following Nei (1982), the extent of inter-site variation for each species was estimated for Saskatchewan populations using the statistic $\gamma_{\mathrm{ST}}$; its significance was evaluated by a comparison with a distribution of $\gamma_{\mathrm{ST}}$ values generated by 1000 random shufflings of haplotypes among locations (see Palumbi \& Wilson, 1990).

\section{Results}

Fragment patterns and sizes are set out for each enzyme in Appendix B. Restriction enzymes $A c c \mathrm{I}$, AluI, DraI and Hinfl generated the greatest number of electrophoretic bands. It is likely that this group of enzymes produced an even greater number of (undetected) smaller fragments, given the disparity among fragment size totals. For the remaining endonucleases, average totals of fragment sizes ranged from 15.9 in $H$. viridis to $16.2 \mathrm{~kb}$ in $P$. nebrascensis, values in close agreement with the sum of sizes for the cloned EcoRI pieces. Two (EcoRI, XbaI and $H p a \mathrm{I})$ to eight (HinfI) variants were detected per enzyme. The majority of patterns was shared by two or more species. For example, variant $\mathrm{A}$ of $E c o \mathrm{RI}$ was found in all species except $M$. confusus and $M$. gladstoni. Each of seven enzymes exhibited polymorphism for fragment patterns in at least one of five species. All species except $M$. packardii displayed pattern A of XbaI. $H$. viridis possessed the largest number of unique patterns.

Altogether, 30 different composite genotypes were revealed among the 11 species (Appendix A). All haplotypes were species-specific except for haplotype 4 , detected in one $M$. sanguinipes and nine $M$. dawsoni individuals.

Table 1 lists two measures of within-species diversity: number of haplotypes and average diversity $(\pi)$ values. $M$. sanguinipes, $M$. femurrubrum, $M$. bivittatus, M. packardii and M. dawsoni were polymorphic for 12 , $5,3,3$ and 2 haplotypes, respectively, with certain haplotypes predominating (Appendix A). Over 90 per cent of $M$. bivittatus were haplotype 12; two haplotypes, 15 and 16 , were equally represented in $M$. packardii; haplotypes 18 and 19 comprised over 70 per cent of $M$. femurrubrum and $M$. dawsoni was mostly genotype 4 . Over 50 per cent of $M$. sanguinipes were either haplotype 1 or 5 (Chapco et al., 1992). Only one haplotype was revealed for each of the remaining species. Divergences $(\delta-$ not recorded $)$ between pairs of haplotypes ranged from 0.18 per cent (for several pairs of mtDNA morphs in $M$. sanguinipes) to 1.40 per cent representing the most disparate pair, haplotypes 12 and 14 in M. bivittatus. Average percentage nucleotide diversities $(\pi)$ in polymorphic species 
ranged from 0.06 ( $M$. dawsoni $)$ to 0.31 (M. femurrubrum).

The last column on Table 1 records the extent of intraspecific variation $\left(\gamma_{\mathrm{ST}}\right)$ that is attributable to among-site variation. The amount of differentiation for $M$. sanguinipes is significantly greater than that expected by random shuffling. Values for other species are not significant with that of $M$. packardii bordering on significance. Outside the major study area, limited sampling revealed haplotypes which also occur in Saskatchewan. For example, one $M$. bivittatus and two $M$. infantilis individuals collected at Turtle Lake, ND, possessed haplotypes 12 and 22, respectively. One exception is provided by a single $M$. femurrubrum individual collected in Alexandria, $\mathrm{MN}$, which possessed a unique haplotype (30).
Interspecific nucleotide diversities $(\pi)$, corrected for within species variation, are recorded in Table 2 . Within the genus Melanoplus, values ranged from 0.29 per cent (between $M$. dawsoni and $M$. sanguinipes) to 4.38 per cent (between $M$. packardii and $M$. confusus). On average, the most distant species was $H$. viridis with a maximum value of 7.96 per cent separating it from $P$. nebrascensis. Interestingly, the latter species, although outside the Melanoplus genus, was more similar to some members (e.g. M. bivittatus) than some Melanoplus species were to each other (e.g. M. packardii and M. confusus).

An overall interpretation of these distances is provided by the NJ network depicted in Fig. 1 . Connections among taxa agree reasonably well with those suggested by a majority-rule consensus tree (Fig.

Table 1 Mitochondrial DNA variation and interpopulational diversities for 11 species of melanoplines

\begin{tabular}{|c|c|c|c|c|c|}
\hline Species & Sample size ${ }^{\mathrm{a}}$ & $\begin{array}{l}\text { Number of } \\
\text { populations }\end{array}$ & $\begin{array}{l}\text { Number of } \\
\text { haplotypes }^{\mathrm{a}}\end{array}$ & $\begin{array}{l}\text { Percentage } \\
\operatorname{diversity}(\pi)\end{array}$ & $\begin{array}{l}\text { Percentage } \\
\text { interpopulational } \\
\text { diversity }\left(\gamma_{\mathrm{ST}}\right)\end{array}$ \\
\hline$M$. sanguinipes & $75(89)$ & $14(19)$ & 12 & 0.26 & $27.4(0.003)^{\mathrm{b}}$ \\
\hline M. bivittatus & $53(54)$ & 12 & 3 & 0.12 & $<0.0(0.75)$ \\
\hline M. packardii & 30 & 9 & 3 & 0.20 & $27.5(0.05)$ \\
\hline M. femurrubrum & $11(12)$ & $4(5)$ & $4(5)$ & 0.31 & $53.1(0.08)$ \\
\hline M. dawsoni & 10 & 4 & 2 & 0.06 & - \\
\hline M. angustipennis & 4 & 1 & 1 & 0.00 & - \\
\hline M. confusus & $4(12)$ & 2 & 1 & 0.00 & - \\
\hline M. gladstoni & 5 & 1 & 1 & 0.00 & - \\
\hline M. infantilis & $10(12)$ & $3(4)$ & 1 & 0.00 & - \\
\hline P. nebrascensis & 4 & 1 & 1 & 0.00 & - \\
\hline H. viridis & 4 & 1 & 1 & 0.00 & - \\
\hline
\end{tabular}

${ }^{a}$ Values are for Saskatchewan populations. Values in parentheses in columns 2-4 are for all populations. ${ }^{b}$ Proportion of 1000 simulated values which exceed the observed value.

Table 2 Percentage nucleotide diversity $(\boldsymbol{\pi})$ within species (diagonal) and between species (corrected for within species variation)

\begin{tabular}{|c|c|c|c|c|c|c|c|c|c|c|c|}
\hline Species & 1 & 2 & 3 & 4 & 5 & 6 & 7 & 8 & 9 & 10 & 11 \\
\hline 1. M. sanguinipes & 0.256 & & & & & & & & & & \\
\hline 2. M. bivitattus & 1.163 & 0.123 & & & & & & & & & \\
\hline 3. M. packardii & 3.260 & 3.275 & 0.196 & & & & & & & & \\
\hline 4. M. femurrubrum & 0.910 & 1.895 & 2.472 & 0.312 & & & & & & & \\
\hline 5. M. dawsoni & 0.289 & 1.286 & 3.281 & 1.087 & 0.058 & & & & & & \\
\hline 6. M. confusus & 2.814 & 2.105 & 4.380 & 3.702 & 2.849 & 0.000 & & & & & \\
\hline 7. M. infantilus & 3.061 & 1.755 & 3.426 & 1.664 & 3.185 & 3.926 & 0.000 & & & & \\
\hline 8. M. gladstoni & 1.892 & 1.466 & 2.438 & 2.985 & 1.512 & 1.390 & 3.822 & 0.000 & & & \\
\hline 9. M. angustipennis & 0.847 & 1.377 & 3.207 & 1.836 & 0.510 & 2.633 & 3.519 & 0.948 & 0.000 & & \\
\hline 10. P. nebrascensis & 2.888 & 2.264 & 6.294 & 4.708 & 2.979 & 3.854 & 4.751 & 2.880 & 2.608 & 0.000 & \\
\hline 11. H. viridis & 4.598 & 4.647 & 7.171 & 5.071 & 5.303 & 6.262 & 5.826 & 6.471 & 6.032 & 7.761 & 0.000 \\
\hline
\end{tabular}


2) based on over 100 equally parsimonious trees (115 steps). The latter was constructed using the most disparate taxon, $H$. viridis, as an outgroup. Either topology illustrates: (1) a close association among $M$. sanguinipes, $M$. angustipennis and $M$. dawsoni, (2) a connection between $M$. bivittatus and $P$. nebrascensis, and (3) linkages among $M$. packardii, $M$. femurrubrum and $M$. infantilis. The latter is apart from a larger group consisting of $(1),(2), M$. confusus and $M$. gladstoni.

\section{Discussion}

All surveyed species possess mtDNA of approximately the same length, about $16.1 \mathrm{~kb}$ on average, well within the range of most metazoans, including insects (Chapco et al., 1992). None of the banding patterns displayed by single individuals suggests that these species might be heteroplasmic for two or more size classes of mtDNA, as is the case for a number of invertebrates (Boyce et al., 1989).

Intraspecific diversities $(\pi=0.00$ to 0.31 per cent $)$ are about the same or less than that reported previously for $M$. sanguinipes and are in the lower spectrum of values for most insects (Chapco et al., 1992). Small sample sizes $(n=4,5)$ could reasonably account for a failure to detect more than one haplotype in studies involving $M$. angustipennis, $M$. gladstoni, $H$. viridis and $P$. nebrascensis. This could also be true for $M$. dawsoni and $M$. infantilis for which numbers of assayed insects are somewhat larger $(n=10-12)$ although $M$. femurrubrum with a comparable sample size is much more diverse. Low mutation rates and purifying selection, among other factors, have been discussed in relation to low diversity (Martin \& Simon, 1990). A more probable and appealing explanation, however, rests in the sensitivity of genetic variation, especially mtDNA variation, to events associated with reductions in population size (Wilson et al., 1985). Such was probably the case during various glacial

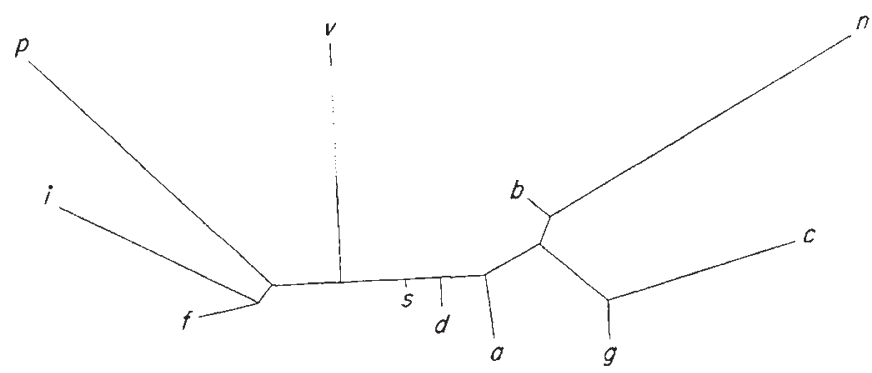

Fig. 1 Neighbour-joining tree based on average nucleotide divergence $(\pi \times 100)$ between pairs of melanopline species. Letters represent the first letter of the species name (Appen$\operatorname{dix}$ A). Dotted line connecting species $v=4.4$ per cent. episodes and prior to the transition to an agroecosystem (see Chapco et al., 1992 for further discussion). Irregular fluctuations in abundance have also occurred in this century that have been attributed to climatic variation, disease, changes in the agricultural landscape and herbicide use (Riegert, 1968, 1986). Of course the relative impact of these historical events can only be speculated upon. Indeed, it is only now that theory is being developed for inferring connections between previous demographic occurrences and sequence or restriction site data (Slatkin \& Hudson, 1991; Rogers \& Harpending, 1992).

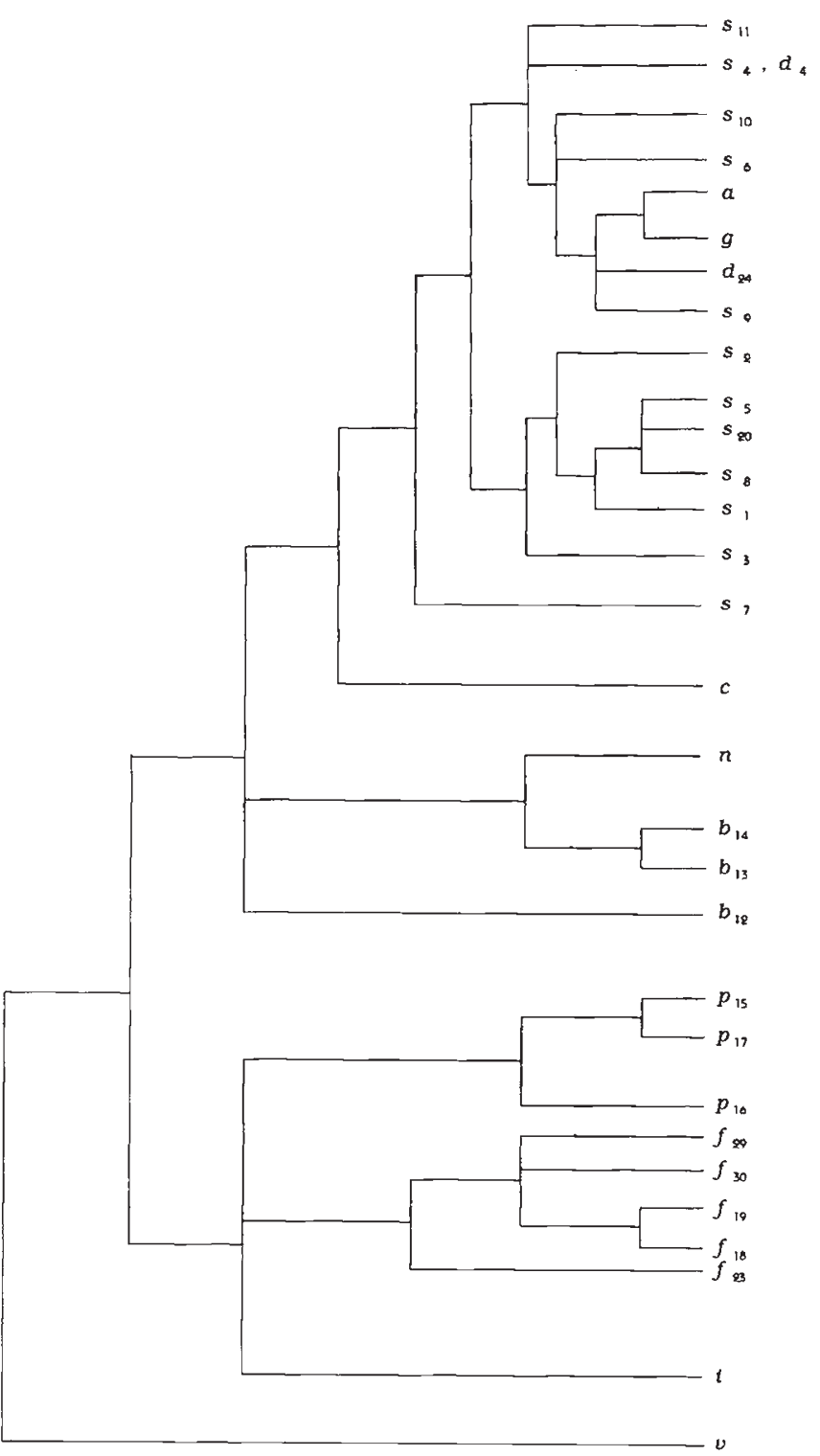

Fig. 2 Majority-rule consensus of 100 trees of equal length (115 steps), each constructed by the maximum parsimony method. Letters refer to the first letter of the species name. Subscripted letters indicate specific haplotypes. Hesperotettix viridis $(v)$ was used to root the tree. 
The first four species listed in Table 1 are frequently listed among the top six grasshopper pests in North America (Beirne, 1972; Vickery \& Kevan, 1986); the greatest amount of mtDNA variation is also exhibited by these species, including $M$. femurrubrum in spite of the small sample taken. Whether there is a connection between variability and fluctuation in abundance (see Lorimer (1979) and Carson (1990) for theoretical arguments) is a hypothesis certainly worth pursuing in the case of grasshoppers. Present data, although indicative of a relationship, are unfortunately insufficient to be definitive. Larger sample sizes and more extensive samplings of the genome are required.

In the previous study involving $M$. sanguinipes, it was concluded on the basis of the numerical value of Nei's interpopulational nucleotide diversity index $\gamma_{S T}$ that there was very little differentiation among sites for this species. While the statistical test indicates otherwise, an examination of Table 1 in Chapco et al. (1992) reveals that this results mainly from the presence of a few geographically restricted haplotypes (10 and 20 in Hudson Bay and 7 and 8 in Assiniboia and Horizon). If these data are omitted, $\gamma_{\mathrm{ST}}$ reduces to 6.49 , a non-significant value $(P=0.22)$. The near-significant $\gamma_{\mathrm{ST}}$ for $M$. packardii stems largely from the presence of a single haplotype in one pocket of the study area (Chamberlain); $\gamma_{\mathrm{ST}}$ drops to $9.09(P=0.34)$ if this datum is omitted. No biological meaning should be ascribed to the negative value for $M$. bivittatus. Given the particular array of haplotype frequencies and the hypothesis of no differentiation, about 25 per cent of $\gamma_{\mathrm{ST}}$ values are expected to be 0 or less. In general, common genotypes occur throughout the sampled region, in North Dakota, $\mathrm{MN}$, and in the case of $M$. sanguinipes as far as Ontario and New Mexico. The apparent geographical restriction of certain genotypes is curious, however, given the relative openness of the prairies and an absence of any obvious barriers. A more comprehensive survey of these regions is clearly required.

Apart from some species-group units erected by Scudder (1898), there have been very few published accounts suggesting evolutionary relationships among melanopline grasshoppers. It is even admitted that '.... in most of these (series) ... the collocation is rather forced' (Scudder, 1898, p. 122). In an attempt to identify common factors underlying population fluctuations, Mulkern (1980) clustered various acridids according to a number of bionomic parameters, including the extent of overlap with respect to resource utilization. It is, however, uncertain whether proximity of species on the basis of these parameters stems from convergent evolutionary events or common inheritance. A phylogenetic interpretation of these clusters must, for now, be viewed as premature; indeed, the resolution of the very question of convergence versus common descent can best be addressed when an independently derived evolutionary tree can be obtained, preferably one that is free from environmental vicissitudes. The trees emerging from the current analysis are to be viewed as first approximations of the group's phylogeny owing to the limitations and resolving power of the fragment method (Wilson et al., 1985). Still, given the (apparent) absence of heteroplasmy and generally small $\delta$ values, the approach is a valid one (Nei, 1987; Dowling et al., 1990) and does yield a number of interesting findings. For instance, females of $M$. sanguinipes, M. femurrubrum, $M$. gladstoni and $M$. confusus are to varying extents similar morphologically and difficult to distinguish (Guenther \& Chapco, 1990); yet, based on mtDNA profiles, $M$. sanguinipes is most similar to $M$. dawsoni, a small, usually brachypterous insect and quite unlike the other Melanoplus species. The rather distinctly different mtDNA profiles of $M$. packardii and $M$. bivittatus represent another apparent conflict with morphology; these two species bear a superficial resemblance to one another (Scudder, 1898); members are among the largest organisms in the genus. Analysis of species outside the genus yielded strikingly different outcomes. mtDNA profiles of the green striped grasshopper, $H$. viridis, are unquestionably distinct from those of the other species whereas the large headed grasshopper, $P$. nebrascensis, has an affinity with certain Melanoplus species (e.g. M. bivittatus), closer than that among some Melanoplus species. These results suggest that caution should be exercised in inferring phylogenetic relationships solely on the basis of one type of trait. Indeed, Moritz \& Hillis (1990) argue that both morphological and molecular approaches should be utilized in reconstructing phylogenies since both types of characters are subject to different evolutionary forces.

Assuming a conventionally used evolutionary rate of 1.0 per cent substitutions/base pair/lineage/million years (Wilson et al., 1985), the estimated time of common ancestry of the most distant haplotypes (those of $P$. nebrascensis and $H$. viridis) is about 4 million years. The comparable figure for the genus Melanoplus is 2.2 million years. Although these estimates should be regarded as extremely crude, owing to errors of ascertainment associated with evolutionary rates and $\delta$ values, it seems reasonable to suppose that these taxa, or to be more precise - these haplotypes - are fairly recently evolved relative to times that have been speculated for Acrididae and the subfamily Melanoplinae (Gangwere, 1965, 1967; Hewitt, 1979; Jago, 1983).

Portions of the mitochondrial genome of these and other species are currently being sequenced to examine more precisely the populational and phylogenetic 
hypotheses suggested by these restriction fragment data.

\section{Acknowledgements}

This work was supported by grants from the Natural Sciences and Engineering Research Council of Canada to WC and RAK. Financial assistance from the Faculty of Graduate Studies and Research, University of Regina, to DAM is gratefully acknowledged. We thank E. J. Chapco for comments on the manuscript and W. Kuperus for assistance with the figures.

\section{References}

AVISE, J. C., ARNOLD, J., BALL, R. M., BERMINGHAM, E., LAMB, T., NEIGEL, J., REEB, C. A. AND SAUNDERS, N. C. 1987. Intraspecific phylogeography: the mitochondrial DNA bridge between population genetics and systematics. Ann. Rev. Ecol. Syst., 18, 489-522.

BEIRNE, B, P. 1972. Pest insects of annual crop plants in Canada. Part V. Orthoptera. Memoirs of the Ent. Soc. Canada, No. 85, p. 57.

BOYCE, T. M., ZWICK, M. E. AND AQUADRO, C. F. 1989. Mitochondrial DNA in the bark weevils: size, structure and heteroplasmy. Genetics, 123, 825-836.

BRooKs, A. R. 1958. Acridoidea of Southern Alberta, Saskatchewan and Manitoba (Orthoptera). Can. Ent. Supp., 9, 1-92.

CARSON, H. L. 1990. Increased genetic variance after a population bottleneck. Trends Ecol. Evol., 5, 228-230.

CHAPCO, w. 1989. Comparative variation at four enzyme loci in ten Melanopline grasshoppers. Experientia, 45, 196-198.

CHAPCO, W., KELLN, R. A. AND MCFADYEN, D. A. 1992. Intraspecific mitochondrial DNA variation in the migratory grasshopper, Melanoplus sanguinipes. Heredity, 69, 547-557.

DOWLING, T. E., MORITZ, C. AND PALMER, J. D. 1990. Nucleic acids II: Restriction site analysis. In Hillis, D. M. and Moritz, C. (eds), Molecular Systematics, Sinauer. Sunderland MA, pp. 250-317.

FELSEnStein, J. 1988. PHYLIP (Phylogeny Inference Package), Version 3.1 Manual. Seattle, Washington.

GANGWERE, S. K. 1965. The phylogenetic development of food selection in Orthoptera (Sens. Lat.). Proceedings of the XII International Congress in Entomology, pp. 333-334.

GANGWERE, S. K. 1967. The phylogenetic development of food selection in certain orthopteroids. Eos 42, 383-392.

GUENTHER, S. J. AND CHAPCO, w. 1990. A morphometric analysis of Melanoplus females (Orthoptera: Acrididae). PanPacific Ent., 66, 39-42.

GuRney, A. B. 1977. Taxonomic status of the genus Melanoplus, with special reference to the Montanus speciesgroup. Rev. Soc. Ent. Argentina, 36, 85-87.

HANDFORD, R. H. 1946. The identification of nymphs of the genus Melanoplus of Manitoba and adjacent areas. Sci. Agric., 26, 147-180.
HARRISON, R. G. 1989. Animal mitochondrial DNA as a genetic marker in population and evolutionary biology. Trends Ecol. Evol., 4, 6-11.

HELFER, J. R. 1987. How to Know the Grasshoppers, Crickets, Cockroaches and their Allies. Dover, New York.

HEWITT, G. M. 1979. Grasshoppers and crickets. Animal Cytogenetics, vol. 3, Insecta, I Orthoptera. Gebruder Borntraeger, Berlin-Stuttgart.

JAGO, N. D. 1983. The breakup of Pangaea and prediction of numbers of subfamily elements, living and extinct, in Acridoidea. Proc. Pan. Am. Acrid. Soc., 2, 139-162.

LoCKWOOD, J. A. 1989. Taxonomic status of the Rocky Mountain locust: morphometric comparisons of Melanoplus spretus (Walsh) with solitary and migratory Melanoplus sanguinipes (F.). Can. Ent., 121, 1103-1109.

LORIMER, N. 1979. Genetic causes of pest population outbreaks and crashes. In: Hay, A. M. and McKervey, J. S. (eds), Genetics in Relation to Insect Management. Rockefeller Foundation, New York.

MARTIN, A. AND SIMON, C. 1990. Differing levels of amongpopulation divergence in the mitochondrial DNA of periodical cicadas related to historical biogeography. Evolution, 44, 1066-1080.

MORITZ, C. AND HILLIS, D. M. 1990. Molecular systematics; context and controversies. In Hillis, D. M. and Moritz, C. (eds), Molecular Systematics, Sinauer, Sunderland, MA, pp. $1-10$.

MULKERN, G. B. 1980, Population fluctuations and competitive relationships of grasshopper species (Orthoptera: Acrididae). Trans. Am. Ent. Soc., 106, 1-41.

NEI, M. 1982. Evolution of human races at the gene level. In Bonné-Tamir, B. (ed.), Human Genetics, Part A: The Unfolding Genome, Liss, New York, pp. 167-181.

NEI, M. 1987. Molecular Evolutionary Genetics. Columbia University Press, New York.

NEI, M. AND LI, W.-H. 1979. Mathematical model for studying genetic variation in terms of restriction endonucleases. Proc. Natl. Acad. Sci. U.S.A., 76, 5269 5273.

ONSAGER, J. A. AND MULKERN, G. B. 1963. Identification of eggs and egg-pods of North Dakota grasshoppers (Orthoptera: Acrididae). Tech. Bull. N. Dakota St. Univ. Agric. Exp. Stn., 446, 1-48.

OTTE, D. 1981. The North American Grasshoppers, vol. I. Acrididae: Gomphocerinae and Acridinae. Harvard University Press, Cambridge, MA.

PALUMBi, S. R. AND WILSON, A. C. 1990. Mitochondrial DNA diversity in the sea urchins Strongylocentrotus purpuratus and $S$. droebachiensis. Evolution, 44, 403-415.

RIEGERT, P. W. 1968. A history of grasshopper abundance surveys and forecasts of outbreaks in Saskatchewan. Memoirs of the Ent. Soc. Canada, No. 52, pp. 99.

RIEGERT, P. W. 1986. The effect of perturbations on the stability and diversity of grasshopper species on the North American prairies. Proc. Pan. Am. Soc., 4, 111-120.

ROGERS, A. R. AND haRPENDing, H. 1992. Population growth makes waves in the distribution of pairwise genetic differences. Mol. Biol. Evol., 9, 552-569.

SAITOU, N. AND NEI, M, 1987. The Neighbor-Joining method: a new method for reconstructing phylogenetic trees. Mol. Biol. Evol., 4, 406-425. 
SCUDDER, S. H. 1898. Revision of the orthopteran group Melanopli (Acrididae) with species reference to North American forms. Proc. U.S. Natn. Mus., 20, 1-421.

SLATKIN, M. AND HUDSON, R. R. 1991. Pairwise comparisons of mitochondrial DNA sequences in stable and exponentially growing populations. Genetics, 129, 555-562.

VICKERY, v. R. 1987. The northern Nearctic orthoptera: their origins and survival. In Baccetti, B. (ed.), Evolutionary Biology of Orthopteroid Insects, Horwood, Chichester, pp. 581-590.

VICKERY, V. R. AND KEVAN, D. K. MCE. 1986. The Grasshoppers, Crickets and Related Insects of Canada and Adjacent Regions. Ulonata: Dermaptera, Cheleutoptera, Notoptera,
Dictuoptera, Grylloptera and Orthoptera. The Insects and Arachnids of Canada. Part 14. Research Branch Agriculture Canada Publication No. 1777.

VICKERY, V. R. AND SCUdDER, G. G. E. 1987. The Canadian orthopteroid insects summarized and updated, including a tabular check-list and ecological notes. Proc. Ent. Soc. Ont., 118, 25-45.

WILSON, A. C., CANN, R. L., CARR, S. M., GEORGE, M., GYLLENSTEN, U. B., HELM-BYCHOWSKI, K. M., HIGUCHI, R. G., PALUMBI, S. R., PRAGER, E. M., SAGE, R. D. AND STONEKING, M. 1985. Mitochondrial DNA and two perspectives on evolutionary genetics. Biol. J. Linn. Soc., 26, 375-400.

Appendix A

Sampling locations and mtDNA haplotypes of 11 melanopline species

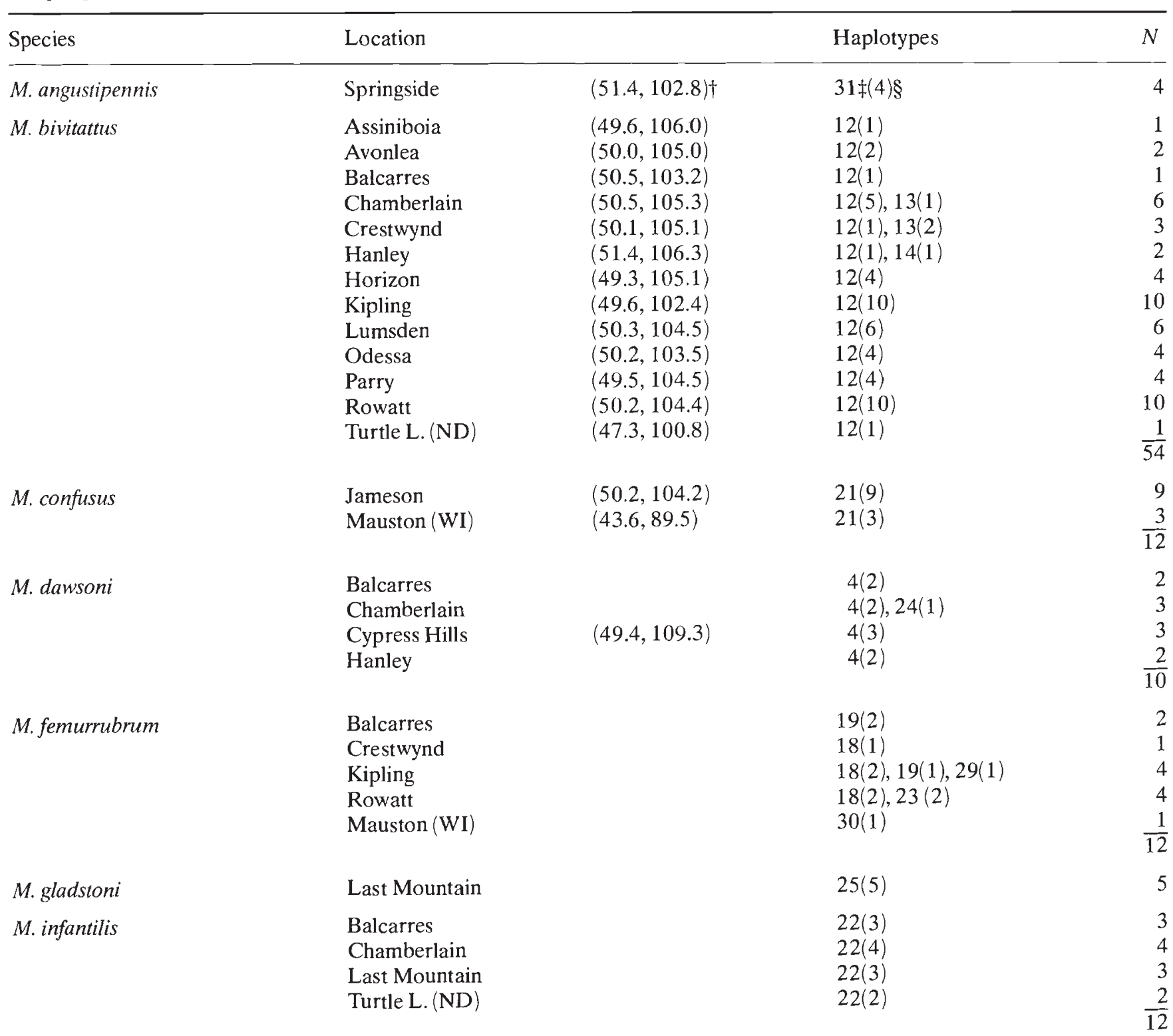


Appendix A Continued

\begin{tabular}{|c|c|c|c|}
\hline Species & Location & Haplotypes & $N$ \\
\hline \multirow[t]{6}{*}{ M. packardii } & Avonlea & $15(1), 16(2)$ & 3 \\
\hline & Crestwynd & $16(2)$ & 2 \\
\hline & Hanley & $15(3)$ & 3 \\
\hline & Lumsden & $15(4), 16(1)$ & 5 \\
\hline & Rowatt & $15(2), 16(1)$ & 3 \\
\hline & Springside & $15(1), 16(2)$ & $\underline{3}$ \\
\hline & & & \\
\hline M. sanguinipes & 19 Locations & Haplotypes 1-11,20 & 89 \\
\hline
\end{tabular}

†Latitude and longitude.

†Haplotypes: 1-11 and 20 defined in Chapco et al. (1992). Letters refer to pattern variants for restriction enzymes listed in the same order as in Appendix B: $4=\mathrm{ABAAAADBAA}, 12=\mathrm{ACABBAABAA}, 13=\mathrm{ACBBBABBA}, 14=\mathrm{ACBCBABBAA}$, $15=\mathrm{ACACBBCAAB}, 16=\mathrm{ACACBBDAAB}, 17=\mathrm{ACCCBBCAAB}, 18=\mathrm{ABAAAAABAB}, 19=\mathrm{ABAAAAAAAB}$, $21=\mathrm{BCACBAEBBA}, 22=\mathrm{ACABCAFBCB}, 23=\mathrm{ABABAAABAB}, 24=\mathrm{ABAAAAGBAA}, 25=\mathrm{BCACBAGBAA}$, $29=\mathrm{AAAAAAABAB}, 30=\mathrm{ABAABAABAB}, 31=\mathrm{ACAAAAGBAA}, 32=\mathrm{ADBDEAAADC}, 33=\mathrm{ACAEDAHBAA}$. $\S$ Number of individuals. $N=$ sample size. 
Appendix B

Restriction fragment patterns and sizes

\begin{tabular}{|c|c|c|c|}
\hline Enzyme & Pattern & Fragment sizes $(b p)$ & Species $\dagger$ \\
\hline Eco RI & $\begin{array}{l}\text { A } \\
\mathrm{B}\end{array}$ & $\begin{array}{l}8000,6800,1200 \\
8000,3800,3000,1200\end{array}$ & $\begin{array}{l}\mathrm{a}, \mathrm{b}, \mathrm{d}, \mathrm{f}, \mathrm{i}, \mathrm{n}, \mathrm{p}, \mathrm{s}, \mathrm{v} \\
\mathrm{c}, \mathrm{g}, \mathrm{s}\end{array}$ \\
\hline$B g l I I$ & $\begin{array}{l}\text { A } \\
\text { B } \\
\text { C } \\
\text { D }\end{array}$ & $\begin{array}{l}6800,5600,2400,1200 \\
7800,6800,1200 \\
16300 \\
10500,5000\end{array}$ & $\begin{array}{l}f, s \\
d, f, s \\
a, b, c, g, i, n, p \\
v\end{array}$ \\
\hline Pst $\mathrm{I}$ & $\begin{array}{l}\text { A } \\
\text { B } \\
\text { C }\end{array}$ & $\begin{array}{l}16300 \\
12000,4300 \\
8000,7800\end{array}$ & $\begin{array}{l}\text { a, b, c, d, f, g, i, n, p, s } \\
\text { b, v } \\
\text { p }\end{array}$ \\
\hline$A c c \mathbf{I}$ & $\begin{array}{l}\text { A } \\
B \\
C \\
D \\
\text { E }\end{array}$ & $\begin{array}{l}8800,4800,2600 \\
12000,4200 \\
7500,4300,2600,1300 \\
8600,4000,1600,1400 \\
6500,5800,4000\end{array}$ & $\begin{array}{l}a, d, f, s \\
b, f, i \\
b, c, g, p \\
v \\
n\end{array}$ \\
\hline$P v u \mathrm{II}$ & $\begin{array}{l}\text { A } \\
\text { B } \\
\text { C } \\
\text { D } \\
\text { E }\end{array}$ & $\begin{array}{l}13400,2600 \\
16300 \\
11000,5000 \\
9000,7500 \\
\text { uncut }\end{array}$ & $\begin{array}{l}a, d, f, s \\
b, c, f, g, p, s \\
\text { i } \\
\text { n } \\
\text { v }\end{array}$ \\
\hline$X b a \mathrm{I}$ & $\begin{array}{l}\text { A } \\
\text { B }\end{array}$ & $\begin{array}{l}7300,4400,2100,1600,600 \\
8500,2600,1900,1800\end{array}$ & $\begin{array}{l}\mathrm{a}, \mathrm{b}, \mathrm{c}, \mathrm{d}, \mathrm{f}, \mathrm{g}, \mathrm{i}, \mathrm{n}, \mathrm{s}, \mathrm{v} \\
\mathrm{p}\end{array}$ \\
\hline HinfI & $\begin{array}{l}\text { A } \\
\text { B } \\
\text { C } \\
\text { D } \\
\text { E } \\
\text { F } \\
\text { G } \\
\text { H }\end{array}$ & $\begin{array}{l}3700,2600,1200,700,600,500,450 \\
4000,2300,1200,700,600,500,450 \\
3700,2600,1400,900,700,600,450,400 \\
3700,2600,1200,900,700,600,500,450,400 \\
2600,1700,1500,1200,700,600,500,450 \\
3700,2600,1700,1200,600,500,450 \\
2600,1200,900,700,600,550,450,400 \\
2800,1200,950,750\end{array}$ & $\begin{array}{l}\mathrm{b}, \mathrm{f}, \mathrm{s}, \mathrm{v} \\
\mathrm{b} \\
\mathrm{p} \\
\mathrm{d}, \mathrm{s}, \mathrm{p} \\
\mathrm{c} \\
\mathrm{i} \\
\mathrm{a}, \mathrm{d}, \mathrm{g}, \mathrm{s} \\
\mathrm{n}\end{array}$ \\
\hline MpaI & $\begin{array}{l}\text { A } \\
\text { B }\end{array}$ & $\begin{array}{l}13300,1700,1000 \\
15000,1000\end{array}$ & $\begin{array}{l}\mathrm{f}, \mathrm{p}, \mathrm{s}, \mathrm{v} \\
\mathrm{a}, \mathrm{b}, \mathrm{c}, \mathrm{d}, \mathrm{f}, \mathrm{g}, \mathrm{i}, \mathrm{n}, \mathrm{s}\end{array}$ \\
\hline Dra I & $\begin{array}{l}\text { A } \\
\text { B } \\
\text { C } \\
\text { D }\end{array}$ & $\begin{array}{l}1750,1600,1250,1000,850,700,575,400 \\
3900,2300,1600,1250,1150,600,550,400 \\
3700,1750,1000,850,575,400 \\
2100,1100,850,700,650,550,450\end{array}$ & $\begin{array}{l}a, b, d, f, g, n, p, s \\
c \\
i \\
v\end{array}$ \\
\hline Alu $\mathbf{I}$ & $\begin{array}{l}\text { A } \\
\text { B } \\
\text { C }\end{array}$ & $\begin{array}{l}2100,1300,900,800,700,600,450,400,375 \\
2000,1600,1300,900,800,700,565,375 \\
1400,950,800,600,500\end{array}$ & $\begin{array}{l}\text { a, b, c, d, g, n, s } \\
\text { f,i,p } \\
\text { v }\end{array}$ \\
\hline
\end{tabular}

$\dagger$ Letters represent the first letter of the species name. 